\title{
Some Remarks on the Persistent Objector Rule in Customary International Law Olufemi Elias ${ }^{\star}$
}

Since the publication of the first edition of Brownlie's Principles of Public International Law in 1966, the term "persistent objector" has become a term of art in international law. ${ }^{1}$ Subsequent discussion ${ }^{2}$ of the subject (in which there has been considerable interest particularly in the last decade) reveals a polarity of opinion; the majority of writers (hereinafter "optimists") confirm the existence and vitality of the rule, while some writers (hereinafter "sceptics") would not. The sceptical views range from the general (for example, that there is little or no role for the persistent objector rule to play whether in theory or in practice $)^{3}$ to more qualified pessimism (for example, that there is a role for the rule in theory which has not been played in practice). ${ }^{4}$ The purpose of this article is not to deal comprehensively with all aspects of the persistent objector rule. ${ }^{5} \mathrm{It}$ is, rather, to suggest that even if this scepticism is ultimately justified, many of the arguments upon which it is based do not provide compelling reasons for the rejection of the principle in contemporary international law-making. This will be done by examining three issues: the actual formulation of the persistent objector rule itself,

* Lecturer in Law, University of Buckingham. The author wishes to thank Professor M. H. Mendelson and Dr A. V. Lowe for their patient discussion of an earlier draft of this paper.

1. Brownlie, Principles of Public Intemational Law 1st ed. (1966), p. 8; 2nd ed. (1973), p. 10; 3rd ed. (1979), pp. 10-11; 4th ed. (1990), p. 10.

2. The authorities sometimes deal with the subject without direct reference to the "persistent objector"; the following list is not, therefore, exhaustive: Kelsen-Tucker, General Principles of International Law 2nd ed. (1966), pp. 446-48; D'Amato, The Concept of Custom in Intermational Law (1971), pp. 187-199, “On Consensus", 8 Canadian Y.I.L. (1970), pp. 104, 108, and International Law: Process and Prospect (1987), generally Chs, 1, 5 and 6; Thirlway, International Customary Law and Codification (1972), p. 110; Akehurst, "Custom as a Source of International Law", 47 (1974-5) B.Y.I.L., pp. 23-27; Bos, A Methodology of International Law (1983), pp. 247-255; Charney, "The Persistent Objector Rule and The Development of Customary International Law", 56 (1985) B.Y.I.L., pp. 1-24; Stein, "The Approach of the Different Drummer: the Principle of the Persistent Objector in International Law", 26 (1985) Harvard I.L.fo., pp. 457-82; Colson, "How Persistent Must The Persistent Objector Be?", 61 (1986) Washington L.R., pp. 957-970; Koskenniemi, From Apology to Utopia (1989), pp. 393-95.

3. Charney, supra n. 2.

4. Stein, supra n. 2.

5. The authorities cited in $\mathbf{n} .2$ supra, especially Stein and Charney, provide more general and detailed treatment of the issues involved. 
the state practice relied upon by the sceptics, and the theoretical basis of the sceptical position.

Trite (though perhaps somewhat artificial) as it may seem, it is important at the outset to restate the distinction between the "persistent" and the "subsequent" objector. ${ }^{6}$ We are concerned here only with the former, that is, the State that objects to a rule of customary international law at the time of the formation of the rule, as opposed to a State that objects later on. None of the authoritative texts would permit a State to opt out of an existing rule of customary international law, and not many would subscribe to the view that new States can choose to exempt themselves from the application of an existing rule. ${ }^{7}$ And practically speaking, a State that objects after a rule has come into existence is necessarily attempting to change the rule, and for it to show that it is not bound by that rule may prove to be a difficult task; as Bos puts it, ". . . the objector-State may have to accept the consequences of what might be considered to be a change of heart ..." 8 There may well be cases in which the distinction between persistent objection and subsequent objection is difficult to draw, ${ }^{9}$ but in principle the distinction is not problematic.

\section{The definition of the persistent objector rule}

A striking feature of discussions about the existence and vitality of the persistent objector rule is the lack of a common statement of the rule itself. Brownlie is concerned with "the rule that a State may contract out of a custom in the process of formation." 10 Similarly, Akehurst states that

"The question therefore is whether a State can prevent a rule of customary law becoming binding on it in the first place."11

According to these jurists, the question is whether it is permissible in international law for a State to avoid the opposability of a particular rule to that State, and the answer is in the affirmative, subject to the rebuttal of a probable presumption of acceptance.

6. Brownlie, supra n. 1, 4th ed., pp. 10-11.

7. The position is encapsulated in the Draft of the Restatement of the Foreign Relations Law of the United States (Revised) in Comment (d) on Section 102:

"Dissenting views and new States ... a dissenting state which indicates its dissent from a practice while the law is still in the process of development is not bound by that rule of law even after it matures ... A state that enters the international system after a practice has ripened into a rule of international law is bound by it."

8. Bos, supra n. 2.

9. E.g., while the literature shows that many supporters of the rule are quick to cite the AngloNorwegian Fisheries Case (1951) I.C.J. Reports 116, the discussion by Brownlie (supra n. 5) shows that the International Court treated the matter as one of subsequent objection on Norway's part plus acquiescence on the part of other States.

10. Supra n. 6.

11. Supra n. 2, p. 24. 
One may compare these formulations with those of another kind. For instance, Bos asks the question whether a State "can" be bound by a rule in spite of the fact that it fails to have the relevant opinio juris or that it displays a different opinio juris in relation to that rule. ${ }^{12}$ Kelsen states that

"It is possible to assume that a state is bound by international law only if it recognises this law as binding upon it ... But there is hardly a writer ready to accept all the consequences of such an assumption." 13

According to this category of formulation, the question is whether a State can be bound in respect of a rule to which it has always objected. Interestingly, the answer is also in the affirmative. Kelsen does not examine the scope of his answer, while Bos does, but they both give the same answers.

We may now compare and contrast the two categories of formulation. The first category seeks to find out whether a State can avoid being bound by a rule to which it has persistently objected, and the answer is affirmative. The second category seeks to find out whether a State can be bound by a rule in spite of its persistent objection, and again the answer is affirmative. A semantic problem becomes apparent. The first category says a State can avoid the obligation while the second says it can be bound. The problem is that these two categories are hardly mutually exclusive. There is a gap left uncovered by these formulations. Dealing with one category exclusively does not tell the whole story. At this purely semantic level, it is at least perfectly possible that there is no necessary disagreement as to the existence of the persistent objector rule at all. Perhaps it is not a coincidence that the first category is that of optimists (Brownlie and Akehurst), while the second is that of sceptics (Bos and Kelsen). It appears (to borrow Stein's metaphor) that they are each dancing to the rhythm of a drummer which cannot be heard by the other. If the disagreement is to be substantiated, the truth conditions of the one category must be compared with those of the other - only then will the real bone of contention be revealed, and then dealt with.

The problem can be illustrated by a scrutiny of Bos' thesis. ${ }^{14} \mathrm{He}$ argues that the psychological element required for the formation of a rule of general customary international law is opinio and not voluntas, and that since the latter, being the will of the actor, cannot be generalised to the point where it becomes the referent for determining what counts as law, then "there is no room for voluntarism." 15 This is, however, at least controversial; so, unlike Unger, ${ }^{16}$ Bos qualifies this by looking

12. Supra, n. 8.

13. Supra, n. 2. Charney's interpretation that Kelsen argues that "international law is binding even on the dissenting State" is not supported by this text (see Charney, supra n. 2, at p. 3, n. 9).

14. Supra, n. 2 .

15. Ibid., p. 221.

16. R. Fidelio Unger, Volkergewohnheit strecht-objektives Recht odes Geflect bilaterales Beziehungen? (1978), pp. 10, 53-55, 68-70, 74-76, 149. 
at "values". If the "weight" of the value sought to be protected by a rule is "overpowering", the persistent objector "should not be excluded from the applicability of the rule which, to all intents and purposes, may be considered to be ius cogens."'17

This view shifts from description to prescription and back again, without any warning. In any case, other difficulties are raised. There is still much to be discovered about ius cogens. ${ }^{18}$ How is a norm of ius cogens created? What is meant by the "international community as a whole" in Article 53 of the Vienna Convention on the Law of Treaties? It appears that the category of $i$ us cogens is still largely an empty box, subject to a few possible exceptions. And while we seek to establish whether, and if so when, a State can benefit from persistent objector status in relation to rules of custom, with considerable difficulty, this thesis takes us into the even more shaky area of ius cogens. It holds some water only if it can be shown that rules of ius cogens come into force through the same process that creates customary international law, but there are not many bigger "ifs" than this where international law-making is concerned. ${ }^{19}$ The answer to the problem, in Wittgenstein's words, is not to introduce more flies into an already congested bottle.

More important for our definitional problem is the question whether, even if the persistent objector is bound by rules of ius cogens, it is bound by customary rules of the character of ius dispositivum? The answer Bos gives is that "... the judge, arbitrators, etc. actually may have a choice," depending on the weight of the values sought to be protected. $A$ fortiori there is room for the persistent objector rule where the umpire decides that the values (a question-begging notion in itself) are not so important. Bos does not tell us anything about cases like these.

Rather than proceeding to provide authority for the proposition that there can be no persistent objector rule where important issues are concerned, Bos examines the evidence in a different way. ${ }^{20}$ For example, in relation to the 1982 United Nations Law of the Sea Convention, he asks, in the light of the United States' obstruction, whether or not the consensus reached over the years 'is not automatically destined to mature into general customary international law on a number of important points." This raises a definitional problem of a different kind. Clearly the persistent objector rule does not operate to prevent a rule from coming into existence for those other States. In fact, that it comes into being is a condition precedent for the persistent objector rule to apply. It is difficult to see why the question is asked at all.

17. Bos, supra n. 2, p. 250.

18. See, e.g., Akehurst, 47 (1974-5), B.Y.I.L., p. 273; Cassese and Weiler(eds.), Change and Stability in International Law-Making (1985), pp. 92-101. The literature on the subject is extensive; see n. 6, supra, at p. 512, n. 25.

19. Charney, supra $\mathrm{n} .2$, appears to treat the creation of rules of ius cogens as being the same as that of custom. But this is problematic - see the authorities cited in $\mathbf{n} .18$ for a discussion of the difficulties. 20. Supra n. 2, pp. 250-55. 
As to whether such law "should be" (as distinct from "is") considered binding on the United States even if it persistently objected to it in some of its aspects, our definitional problem re-emerges. The argument put forward is that the AngloNorwegian Fishers Case ${ }^{21}$ does not say that the persistent objector can never be bound, and that in any case, the alleged 10-mile rule, had it existed, would have been a rule of ius dispositivum. As far as the North Sea Continental Shelf Cases ${ }^{22}$ are concerned, Bos argues that the Court did not treat acceptance of a rule as a conditio sine qua non for the coming into being of a rule of general international law. ${ }^{23}$ To the first argument (that the authorities do not deal with ius cogens) one can reply that the question relates not to ius cogens primarily but to ius dispositivum. To the second argument, one may reply that, while the Court did not require unanimous acceptance, it did not say that acceptance was not important.

So Bos has argued (but it is respectfully submitted, not proved) that a persistent objector will be bound if the rule in question seeks to protect an important value. But what those who support the persistent objector rule argue is precisely the point left untouched by Bos, namely the case where the norm is not ius cogens. Is there really any necessary disagreement here? ${ }^{24}$

If we consider the claims of some of the optimists, who ask whether a State "may" or "can" contract out of a customary rule, ${ }^{25}$ we will see the same kind of definitional difficulty. Brownlie seems to treat it as a simple question of proof "evidence of objection must be clear", clear enough to rebut a probable presumption of acceptance. ${ }^{26}$ There is still, however, the question of what happens even after these conditions are satisfied. In other words, does the objector-state then become exempt from the obligation imposed by the rule once the presumption of acceptance is rebutted? Might it not be the case that there are circumstances in which clear non-acceptance is of itself insufficient to exempt the non-accepting state from the application of the rule in question? This is the kind of point which Bos seeks to make - perhaps there are some values, waiting to be discovered (at worst) or articulated (at best) which might have so much "weight" that individual dissent is insufficient to prevent the operation of the rule erga omnes.

One can see the difficulty in another way - both optimists and sceptics can and do rely on the same authorities. The relevant rule had not come into being in the Anglo-Norwegian Fisheries Case, and so it is no authority for the persistent objector rule, a sceptic would say, but the Court said that even if it had, Norway had persistently objected and was therefore not bound, the optimist would argue. We

21. (1951) I.C.J. Reports, pp. 116, 131.

22. (1969) I.C.J. Reports, p. 3.

23. Clearly this is irrelevant as far as the persistent objector is concerned. The question is not about a rule of general international law coming into being; it is whether, after it has come into being, it binds the persistent objector.

24. See, e.g., Thirlway, supra, n. 2., and Akehurst, supra, n. 18.

25. Supra, n.6 and n.11.

26. Ibid.. 
can reverse the roles for the North Sea Continental ShelfCases. The "equidistance special circumstances" rule had not come into existence, say the optimists, so anything the Court said was obiter; but the sceptics would argue, in Weil's words that

"... however, the implication was that the equidistance rule could otherwise have been imposed upon the Federal Republic even though it had expressly opposed that rule, and even though it was that very opposition which had lain behind its refusal to ratify the Convention."27

The point being made is thus not one that relates to the merits of the different sides of the discussion; rather it is simply that the questions are formulated in a manner that leaves important questions unanswered..$^{28}$ To put it differently, it is one thing to say that it is permissible for $X$ to do $Y$; it is quite another to say that it is always permissible for her so to do. A formulation that might cover all possibilities and therefore seek to provide a circumspect answer would look something like this: "a State that has persistently objected to a rule can never be bound by that rule", for the optimists, or "a State is always bound by a rule of general international law irrespective of its persistent objection", for the sceptics. It is to formulations similar to these that we must now turn, because they attempt to paint the parts of the picture which are not dealt with by discussions tainted by the definitional "sting". 29

\section{The rule in operation: the "missing referent" revisited}

Charney and Stein have provided what may now be regarded as a standard repertoire of test-cases on the operation of the persistent objector rule in practice. It is certainly true that academic support for the rule consists largely of restatements of the rule "with little explanation and few supporting authorities", ${ }^{30}$ and after an examination of possible authorities Charney concludes that "support

27. Weil, "Towards Relative Normativity In International Law", 77 A.f.I.L. (1983), pp. 413, 437 para. 4.

28. It appears that this may sometimes be deliberate. Brownlie's short passage clearly invites further juristic elucidation. One only needs to compare the text(s) on the persistent objector (cited in $\mathrm{n}$. 1, supra), which has remained the same, with the footnotes to these texts, which have changed considerably.

29. Charney does not expressly formulate the principle one way or another. He refers expressly to the formulations by Akehurst, Brownlie and in the Restatement as examples of authoritative formulations of the rule; he thereby avoids the battle lines already drawn. By taking the standpoint of the optimist when he is a sceptic, he deals with the principle in a generally circumspect way. His aim is to examine the "real contribution" of the persistent objector rule "to the development of customary international law." Herein lies the strength of his thesis: see supra n. 3, p. 5.

The formulation in the Restatement, essentially adopted by Stein ("a State that has persistently objected to a rule ... is not bound by that rule: supra n. 2, p. 457, is also an improvement, but it does leave a margin untouched - that between "not" and "never": see n. 6, supra.

30. Charney, supra n. 2. 
for the rule in State practice and judicial decision is limited." 31

The law of the sea is the most fertile area, particularly where the old problem of the limits of territorial sea jurisdiction of coastal States is examined. ${ }^{32}$ The great maritime powers favoured an extensive high seas area and therefore a limited coastal State jurisdiction. In the case of Japan, this caused problems in relation to other Pacific States when the latter claimed twelve-mile exclusive fishery zones especially in the 1960 s onwards. The matter was initially resolved by diplomatic efforts which resulted in agreements which were "intentionally ambiguous" 33 on the question of the legality of such jurisdictional claims. Eventually, however, Japan accepted the new law of the sea, including both the fishery zones and the Exclusive Economic Zones. But was Japan ever bound by these rules without its consent? As Charney admits, ${ }^{34}$ one cannot say, prior to Japan's acceptance, that Japan could only fish with the permission of the coastal States (in which case Japan would be bound in spite of its dissent) because the agreements had another side; the coastal States had to get Japan to relinquish its rights to pursue fishing in certain parts of the zones in question (in which case the States' views were only partially effective against Japan). And after its acceptance, the question becomes superfluous, since Japan had consented. The point is that while Japan was a persistent objector, it was not bound; it only became bound when it ceased to object. But perhaps a more important point is that this is not an example of the persistent objector principle in issue at all. As with the United States ${ }^{35}$ and the United Kingdom, ${ }^{36}$ had Japan not consented to a rule which was still in the process of formation? One may even go so far as to ask whether the acquiescence of these States had not actually finally helped the twelve-mile rule to settle. ${ }^{37}$ In any case, Churchill and Lowe say that "it seems unlikely that there is any State in the position of a persistent objector in this matter", ${ }^{38}$ and it is difficult to state categorically when the rule became settled. The point is the familiar one that law-finding is a difficult task in the system of custom. One only needs to look at the methodology of international tribunals in some of the maritime delimitation cases

31. Charney, supra n. 2, p. 5 . See also, n. 21 and n. 22 supra. See further, Charney's analysis of the Fisheries furisdiction Case (1974) I.C.J. Reports, pp. 10-12, 29-30, 120, 148-9. As with the other cases he discusses, the judicial authorities, at best, fall foul of our definitional "sting"; they are inconclusive: see n. 30, supra, pp. 9-11.

32. Ibid., pp. 11-14, and foomotes thereto.

33. Ibid.

34. Ibid.

35. See the Statement of the President on the Exclusive Economic Zone of 10 March 1983, in the Weekly Compilation of Presidential Documents, Vol. 19, No. 10, p. 383 (14 March 1983).

36. See the Territorial Sea Act 1987.

37. See the historical accounts of the development of the law in this area in Brownlie, supra n. 6, pp. 187-189, and in Churchill and Lowe, The Law of the Sea 2nd ed. (1988), pp. 65-68. See also the judgment of the International Court of Justice in the Fisheries furisdiction case (1974) I.C.J. Reports. The Court avoided a ruling on the legality of Iceland's claim to a 50-mile exclusive fishery zone.

38. Ibid., p. 67. 
they have decided ${ }^{39}$ to confirm this point.

In relation to the United States position on migratory tuna fish, the position is not very different from Japan's in relation to the territorial sea prior to its acceptance. Charney ${ }^{40}$ overlooks the imposition of economic embargoes by the United States in retaliation for the enforcement action taken by coastal States, ${ }^{41}$ and since then, the signature in April 1987 of a Fisheries Treaty by the United States and twelve Pacific Island States, ${ }^{42}$ which would permit American vessels to fish for tuna in parts of the South Pacific Seas, covering ten million square miles. Has the United States' interest then not triumphed? Again, this hardly forces us to reject the persistent objector principle. Either one says that the international law is not completely settled ${ }^{43}$ (in which case we cannot speak of the persistent objector), or one says that it is settled and that the United States dissent, while not having universal application, has paid off in an important way. To put the same point differently, several authoritative texts see custom primarily as a system of bilateral obligations linking two or more states."4 Parry acknowledges ". . . some difficulty about pointing out an unmistakable example of the emergence of a new customary law of general validity." $45 \mathrm{On}$ this widely-held view, rules of custom are not monolithic - hence the importance of individualistic notions such as regional/local customs and, of course, the persistent objector rule. This fundamental notion of opposability must be explained away, and it is submitted that the present example does not do this.

As far as the deep sea bed is concerned, the law is, for the sceptic, at best unsettled, or at worst settled in favour of the Reciprocating States. It has been suggested that any mining that occurs is likely to occur "under either the preparatory investment provisions of the Convention or under the Reciprocating States Regime." 46 Brownlie states that the "dissident States" might be said to have the status of persistent objectors. ${ }^{47}$ Churchill and Lowe express the conundrum nicely:

"Asked if the unilateral legislation is consistent with the various declarations on the deep sea bed, the [International] Court [of Justice] would probably have to say, no. But asked if those declarations bound in law, the reciprocating States not to enact and operate with legislation, the Court

39. See, e.g. Jennings, XXXVIII Annuaire Sursse de Droit Internationale (1981), pp. 59, 65-71. See also Cassese and Weiler, supra n. 18, especially pp. 66-91, and Ch. 1.

40. Supra, n. 2.

41. See Churchill and Lowe, supra n. 37, pp. 237-238.

42. Ibid..

43. As Charney would: supra n. 2, p. 13.

44. See, e.g., Brownlie, supra n. 6; Wolfke, Custom in Present International Law, pp. 11-19; and oddly enough, Kelsen, supra n. 2., pp. 451 et seq..

45. Parry, The Sources and Evidences of International Law, pp. 61-62.

46. Supra n. 37, p. 202.

47. Supra n. 6, p. 256. 
would probably have again to answer, no."48

Again, persistent objection does seem to pay.

With regard to compensation for expropriation, Charney states that the persistent objector rule does not appear to have protected the Western developed States, who still cling to the 'Hull' formula of 1938, from the development of less generous standards and their application against nationals of these States. ${ }^{49}$ If one surveys the literature on the matter, one sees questions ranging from whether the rule ever existed, to whether, even if it did, it still does. Schacter, ${ }^{50}$ for example, questions "whether it has ever been the customary law." Rosseau also points out that the "prompt, adequate and effective" formula has not won general acceptance in practice or in decisions of tribunals. ${ }^{51}$ If these jurists are right, the persistent objector rule is inapplicable; the Western states become subsequent objectors who wish to change the law but have not accumulated the quantum of opiniones individuales juris required to change the existing law, whatever that is. Mendelson, ${ }^{52}$ De Visscher, ${ }^{53}$ Lauterpacht, ${ }^{54}$ and Robinson ${ }^{55}$ maintain that the 'Hull' rule did exist, although they differ as to the effect that subsequent practice and Resolutions may have had on the rule. If this view is right, then the question is whether the old opinio generalis juris has been undermined. If the answer is no (as Mendelson and Robinson would maintain), then the law is still in favour of those who support the rule - and to apply the status of 'objector' to such States would be absurd. If the answer is yes (as Lillich, ${ }^{56} \mathrm{De}$ Visscher and Lauterpacht would argue) then we must ask what it is that has replaced the 'Hull' formula.

Cassese ${ }^{57}$ provides a clear description of the state of the law, pointing out that as any legal regulation of conflicts in expropriation law is at bottom governed by political and economic considerations, one can hardly speak of general customary international law on the matter. This relatively pessimistic view is certainly correct at the auto-interpretative level, ${ }^{58}$ and since we do not have general but special customs, the persistent objector principle is inapplicable. But even at the purer arbitrable/judicial levels, Schacter has stated that at least the cases reveal that the

48. Supra n. 37, pp. 201-202.

49. Supra n. 2, p. 14.

50. Schacter, "Compensation for Expropriation", 78 A.9.I.L. (1984), pp. 121, 122.

51. Rosseau, Vol. V, Droit International Public, pp. 248-50.

52. Mendelson, "Compensation for Expropriation; the Case Law", 79 A.J.I.L. (1985), pp. 414-20.

53. De Visscher, Theory and Reality in International Law (1968), p. 203.

54. Oppenheim, International Law 8th Ed. (1955).

55. Robinson, "Expropriation in the Restatement", 78 A.Y.I.L. (1984), p. 176.

56. Lillich, "The Valuation of Nationalised Property in International Law: Toward a Consensus or More 'Rich Chaos'?", in The Valuation of Nationalised Property in International Law (ed. Lillich) vol. 3 (1975), pp. 345-47.

57. Cassese, International Lavo in a Divided World (1986), pp. 345-47.

58. To borrow the terms used by Cheng, e.g., in "Custom: The Future of State Practice in a Divided World", in McDonald and Johnston, The Structure and Processes of International Law (1983), pp. 522-526. 
property owner is quite likely to get a fair market value and a satisfactory award even though the magic words of the "Hull" formula are not invoked. Tribunals, then, strike compromises. ${ }^{59}$ Brownlie $^{60}$ and Jiménez de Aréchaga, ${ }^{61}$ stressing that "appropriate" compensation is now the norm, have argued that if the term "appropriate" is to have any objective meaning, then failure by the local courts of the host State to provide 'compensation' in an objective sense would be unlawful; reference to domestic law in Article 2 (2)(C) of the Charter of Economic Rights and Duties of $S$ tates $^{62}$ is not a reference to domestic law willy-nilly. "Appropriate" compensation, according to the eminent tribunal in the Aminoil arbitration, is best carried out "by means of an enquiry into all the circumstances relevant to the particular concrete case, than through abstract theoretical discussion." 63 It is therefore misleading to treat the matter as if the Western States' view has been overridden by the view of everybody else, when the reality is that the latter class does not exist. Each part of the world community has a view which does not override that of the others. And clearly, to say that each part is a persistent objector is unhelpful. The 'Hull' formula is therefore not a good illustration of the failure of the persistent objector rule, for the simple reason that the rule is inapplicable to the instance.

Stein ${ }^{64}$ regards the law on sovereign immunity as another example of the rule's lack of vitality. But it is Charney ${ }^{65}$ who shows that it is not an informative example. Pointing out that the Eastern States have been effective in preventing the development of a universal rule of law, because of the "leverage" they have in the matter, he shows that, there being no general rule, the persistent objector principle is inapplicable. This again underscores the importance of the notion of opposability in customary international law. ${ }^{66}$ Once it is accepted (and it is accepted) that the label 'persistent objector' can apply to one state as well as to a group of states, scepticism faces a serious problem. ${ }^{67}$

On the other hand, however, what must be the sceptic's trump card must be the apartheid example. South Africa has not been considered to be free from the rule prohibiting institutionalised racial discrimination in spite of its disguised

59. Schacter, "Compensation Cases: Leading and Misleading", 58 A.f.I.L. (1985), pp. 420, 421.

60. Ibid., pp. 524-543, and Vol. IV, 162 Hague Recueil (1978), pp. 255-71.

61. Jiménez de Aréchaga, 11 New York University fo. of Int. Law and Politics (1978), pp. 179-95; Vol. I, 159 Hague Recueil (1978), pp. 297-310.

62. Resolution 3281 (XXIX), 14 I.L.M. (1975), p. 251; see also Brownlie, supra n. 6, p. 541 for a list of commentaries in $\mathbf{n} .9$.

63. Arbitration between Kuwait and The American Independent Oil Co, 21 I.L.M. (1982), p. 976.

64. Stein, supra n. 2, pp. 460-461.

65. Supra n. 2, at p. 23, n. 94.

66. See supra, nn. $44-45$ and accompanying text.

67. See Koskenniemi, supra n. 2. 
persistent objection. ${ }^{68}$ In the light of the view of the international community "as a whole" 69 and of the International Court, ${ }^{70}$ this is a case where persistent objection is ineffective on a point of settled law.

To conclude, the examination of some of the standard examples of the ineffectiveness of the persistent objector rule does not compel us to reject that rule or to be generally sceptical about it. In fact, some of the scepticism on these examples seems to come perilously close to a confusion of two separate issues; the existence of a rule of law on the one hand, and the enforcement or enforceability of the law on the other. ${ }^{71}$ If the principle is to be rejected we must find other reasons for rejecting it. At this point, the most that can be said for scepticism appears to be that Stein's reservation of his position on the existence of the persistent objector is preferable. ${ }^{72}$

\section{The rule in theory: custom and consent}

If rules of customary international law are based on consent, the category of persistent objector is otiose since dissenting States will not be bound whether or not objection is persistent. If rules of custom are not based on consent, then a State will be bound by a rule whether or not it persistently objects. Whatever the basis of obligation is in international law (for Charney it is the "societal context"), it is what will determine whether or not a State will be bound. This is Charney's formulation of the position. ${ }^{73}$

Thus framed, the proposition strikes at the core of the arguments in support of the persistent objector principle. Brownlie, like all supporters of the principle, certainly treats the consensual nature of custom as its ultimate foundation. ${ }^{74}$ Are these authorities then mistaken? Charney provides a survey of the literature from Kelsen and Brierly, through Fitzmaurice and D'Amato to Alexidze, and concludes that consent is not the basis of obligation in international law, with all possible consequences for the persistent objector. However, a problem arises

68. Counsel for South Africa before the I.C.J. in the Namibia case (see n. 70, infra) argued that South Africa had never violated the principle of racial equality, but that it only promotes and effects separate development for different communities, so that South Africa is not a persistent objector at all. But acceptance of a rule is only half the story; interpretation of any rule is inextricably linked to its acceptance.

69. See Brownlie, supra n. 6, pp. 596-597. The General Assembly each year passes several resolutions condemning apartheid with overwhelming majorities.

70. Legal Consequences for States of the Continued Presence of South Africa in Namibia (South-West Africa) (1971) I.C.J. Reports 12, 57.

71. This seems true in relation to Charney's (and Stein's) claims regarding the territorial sea issue, and also the latter's discussion of the sovereign immunity example. The latter also raises a separate point of classification - can a state be a persistent objector when it does not call itself a persistent objector? Koskenniemi has also underscored this problem. It is submitted that this should not be a separate problem; all that should matter is the evidence of dissent, on which, see Colson, supra $n .2$.

72. Stein, supra n. 2, p. 459 , n. 6.

73. Op. cit., at p. 18 and see generally pp. 16-21. For a survey of the theories on the basis of obligation, see Schacter, "Towards a Theory of International Obligation" (1968) Virginia fo. of Int. Law, p. 300. 74. Supra, n. 1,.p. 10. Cf. the text in the 4th ed., supra n. 6. 
because we need to establish the precise meaning of this near universal rejection of consent. The matter is framed in absolute terms; either consent is the basis of obligation or it is not. Can the matter be phrased so categorically? It appears that not even Kelsen, the arch anti-consensualist, would do this. He states that one can start from the consensualist position, but that "there is hardly a writer ready to accept all the consequences of such an assumption." 75 The truth is that rejection of consent cannot be equated with an absolute elimination of voluntarism; neither does it involve an absolute attribution of universal status to majority rule.

Charney attacks the rejection of "a system of majority voting", but this cannot be taken too far. Much has been written on the present "crisis" in which international law-making finds itself. ${ }^{76}$ The emergence of "soft law" 77 techniques in recent years is a reflection of these developments. Today, the emphasis is on consensus. The lack of socio-political homogeneity in the international system necessitates the compromise that is "soft" law, even though it may mean that the rules will at best be binding in a weak sense. The point is that decisions adopted by a majority in the face of vigorous dissent will hardly produce rules of law that bind everybody. ${ }^{78}$ There is no better evidence of the fact that majority rule is not the norm than the recourse had to the international conference and consensus texts (in spite of the fact that there is a clear majority in, say, the United Nations), in important and diverse fields like human rights, outer space and the environment. As Stein puts it, "A vote, an explanation of position, a refusal to ratify - these are the steps available today that were not available to the States of the classical era."79 So there is now greater facility for the articulation of the voluntaristic traits in the system of custom than there used to be.

\section{Supra n. 2, p. 448.}

76. See Cassese and Weiler, supra n. 26; Chinkin, "The Challenge of Soft Law: Development and Change in International Law", 38 I.C.L.Q. (1989), p. 850 - see bibliography at n. 1 thereto. See also Stein, supra n. 2.

77. This term has been used to cover two separate phenomena - the content of the actual norm itself, on the one hand, and the instrument in which a norm is laid down on the other. In relation to the former, a 'soft' norm is one laid down in legally binding form, such as a treaty, but which is so vague that it amounts to little more than a statement of intent. The problem is that it is difficult to determine with precision what the substance of the legal commitment actually is: see e.g., Part IV of the GATT, or Articles 204(1) or 217(2) of the 1982 U.N. Law of the Sea Treaty.

In relation to the latter (i.e., the instrument in which the norm is laid down), the concern is with instruments such as the Helsinki Final Act and some U.N. General Assembly Resolutions, which contain provisions that are clear and familiar, or which are likely to 'harden' (hence the reservations entered into such provisions in the 1974 Charter of Economic Rights and Duties of States, supra n. 62). The problem here is that these lack the status of full lex lata, as they have not been enacted in ways which satisfy the positivistic pedigree tests of legal validity - treaty stricto sensu and custom (in the sense of established practice).

Both meanings of the term 'soft law' described are the result of political/diplomatic compromise, which, far from being ideal from the point of view of legal certainty, is a necessary evil.

78. Witness the fate of Part XI of the 1982 Law of the Sea Convention: see supra nn. 46-48, and accompanying texts.

79. Stein, supra n. 2, p. 467. 
Koskenniemi has also argued ${ }^{80}$ that while Charney may have discredited voluntarism, he has not replaced it with any explanation of why States are bound by the law. There appears to be much truth in this charge when one analyses Charney's substitute, what he calls "societal context". Simply, we have to be sure that all "contexts" must necessarily exclude voluntarism; otherwise we are simply restating the reality of consent. In other words, societal context is necessarily made up of the sum of the consent of any number of actors on the international scene weighed against the sum of the dissent of other actors. Whenever we speak of "societal context" we are often speaking of consent under a different name.

The truth is that when the sum of consent is greater than the sum of the dissent, there are a number of possibilities. The dissent might simply be overwhelmed, in which case persistent objection is ineffective in law. ${ }^{81}$ Or the dissent may be weaker in a numerical (quantitative) sense, but not in the sense of a qualitative inferiority, (in terms of the influence and interests of the dissenting State(s)). ${ }^{82}$ This can lead to one of two things. The world community may be forced to come down to the level of the State(s) in the minority, ${ }^{83}$ or alternatively, there may be a compromise given the irreconcilability of such differences, with different States having different interests and compromise becoming the best way out of an auto-interpretative stalemate (even if it is not a good way out). ${ }^{84}$ Viewed in this light, it is perfectly possible to strike a middle course between voluntarism and majoritarianism. It appears that all that is meant by rejection of consent is simply a rejection of crude solipsism.

What role is then played by the rule? Stein would argue that, because the law-making process is becoming quasi-institutionalised (in a sense), objection will become much more direct and frequent ${ }^{85}$ But this does not necessarily answer the charge that the traditional role of the persistent objector (as criticised by Charney) is one that is played after the relevant rule is settled. In other words, if international law-making becomes "instant" and "prospective", ${ }^{86}$ any rule, when it "emerges", will already reflect the "societal context", with the result that objection to such a rule becomes otiose. It would then appear that, as Charney said, the real function of the rule is "to force an accommodation of interests in the international community with respect to the evolution of new rules of law." 87 Objection will then not be 'persistent', because it is confined to the formative stages of the customary rule in question.

However, this view fails to account for some features of the law-making process.

80. Supra n. 2, p. 393 (and footnote thereto).

81. The apartheid situation would fall into this category.

82. Charney seems to concede this: supra n. 2, n. 94.

83. Perhaps the examples of the deep sea bed and sovereign immunity could fall into this category.

84. This may explain the fate of the Hull formula (see, supra, nn. 49-63, and accompanying text).

85. Supra n. 2, pp. 463-475.

86. Ibid..

87. Supra n. 2, at p. 23. 
As mentioned above, the international system still displays voluntaristic traits. Firstly, the threshold of legal normativity is becoming increasingly blurred..$^{88}$ This means (a) it is difficult to distinguish between lex lat $a$ and lex ferenda, and this in turn means that (b) it must be difficult to distinguish between persistent and subsequent objection, because the latter distinction (b) relies upon the former (a) ${ }^{89}$ The problem posed by (a) must be explained away if we are to agree with Charney's analysis of the role played by the persistent objector rule. Secondly, as stated above, emphasis on general/settled law can be misleading as to the real nature of law in the international system. This feature, which has been described as "fragmentation", ${ }^{90}$ must also be explained away if we are to circumscribe the role of the persistent objector rule. In sum, if law in general (and international law in particular) is not simply a matter of monolithic "plain-fact" or "pedigree",, 1 the restriction of the role played by the rule is not as compelling as it might seem.

Alternatively, even if one agrees that the rule is confined to the "pre-legal", the fact remains that the objection by states forges a compromise which is reflected in the rule when it "emerges". Still, the function of voluntarism is served, albeit under a label which is not the traditional one of the persistent objector. So rather than reject voluntarism, the most a sceptic can say is that it exists for at least some purpose. What really needs to be addressed, then, is the precise role of consent.

\section{Conclusion}

There are several important questions not dealt with in this paper. How real is the difference between persistent and subsequent objection? ${ }^{92}$ What form must objection take before it can be called objection?" In Stein's article, he points to a number of "vexed questions" 94 which call for attention. All that this paper has

88. See Weil, supra n. 27.

89. See, supra n. 9, and accompanying text.

90. By Koskenniemi, supra n. 2. See, supra, n. 44 and accompanying text.

91. These terms are borrowed from the work of R. Dworkin, in Taking Rights Seriously (1977) and Law's Empire (1986). His theory is but one challenge to the monolithic "completeness" sought after by legal positivism in some of its manifestations. Examples of other works that challenge positivism on this point, with special reference to international law, are McDougal and Reisman, International Law Essays (1981); Falk, "The Relevance of Political Context to the Nature and Functioning of International Law", in The Relevance of International Law (1968), p. 33; Gottlieb, "The Nature of International Law: Towards a Second Concept of Law", in Vol. IV of The Future of the International Legal Order (1974) (eds. Black and Falk), p. 331 and pp. 362-374; D'Amato, supra n. 2; Kennedy, International Legal Structures (1986); Carty, The Decay of International Lazo (1986); and Koskenniemi, supra n. 2. For a more direct use of Dworkin's methodology, see F. Teson, "International Obligation and the Theory of Hypothetical Consent", Yale Y.I.L. (1990), p. 84.

92. See n. 9, supra.

93. See Colson, supra n. 2.

94. At p. 475. To this may be added the precise nature of the relationship between persistent objection and the requirement of generality of practice, a relationship described as "uneasy" by Koskenniemi, supra n. 2, at p. 394 . 
sought to do is indicate some of the difficulties that exist in relation to the persistent objector rule as it has so far been discussed. The subject calls for an "internal" observational standpoint in order to analyse properly the reasons why the persistent objector is prevented from reaping any benefits from objection in some cases but not in others - "external" generalisations are unlikely to be informative. Good reasons must be given for preventing dissenters from obtaining benefits from their dissent, or to put it differently, for the characterisation of such states' actions as illegal. Some of the works examined here do not provide such reasons. 